\title{
Liver X Receptor Agonist Treatment Ameliorates Amyloid Pathology and Memory Deficits Caused by High-Fat Diet in APP23 Mice
}

\author{
Nicholas F. Fitz, ${ }^{1}$ Andrea Cronican, ${ }^{1}$ Tam Pham, ${ }^{1}$ Allison Fogg, ${ }^{1}$ Abdul H. Fauq, ${ }^{2}$ Robert Chapman, ${ }^{2}$ Iliya Lefterov, ${ }^{1}$ \\ and Radosveta Koldamova ${ }^{1}$ \\ ${ }^{1}$ Department of Environmental and Occupational Health, University of Pittsburgh, Pittsburgh, Pennsylvania 15219, and ${ }^{2}$ Chemical Synthesis Core Facility, \\ Mayo Clinic Jacksonville, Jacksonville, Florida 32224
}

\begin{abstract}
High-fat diet and certain dietary patterns are associated with higher incidence of sporadic Alzheimer's disease (AD) and cognitive decline. However, no specific therapy has been suggested to ameliorate the negative effects of high fat/high cholesterol levels on cognition and amyloid pathology. Here we show that in 9-month-old APP23 mice, a high-fat/high-cholesterol (HF) diet provided for 4 months exacerbates the $\mathrm{AD}$ phenotype evaluated by behavioral, morphological, and biochemical assays. To examine the therapeutic potential of liver X receptor (LXR) ligands, APP23 mice were fed HF diet supplemented with synthetic LXR agonist T0901317 (T0). Our results demonstrate that LXR ligand treatment causes a significant reduction of memory deficits observed during both acquisition and retention phases of the Morris water maze. Moreover, the effects of $\mathrm{T} 0$ on cognition correlate with $\mathrm{AD}$-like morphological and biochemical parameters. We found a significant decrease in amyloid plaque load, insoluble $\mathrm{A} \beta$ and soluble $\mathrm{A} \beta$ oligomers. In vitro experiments with primary glia demonstrate that $\mathrm{Abcal}$ is essential for the proper lipidation of $\mathrm{ApoE}$ and mediates the effects of $\mathrm{T} 0$ on $\mathrm{A} \beta$ degradation by microglia. Microdialysis experiments performed on awake freely moving mice showed that T0 decreased $\mathrm{A} \beta$ levels in the interstitial fluid of the hippocampus, supporting the conclusion that this treatment increases $\mathrm{A} \beta$ clearance. The data presented conclusively shows that LXR activation in the context of a metabolic challenge has critical effects on $\mathrm{AD}$ phenotype progression by attenuating $\mathrm{A} \beta$ deposition and facilitating its clearance.
\end{abstract}

\section{Introduction}

Liver X receptors (LXRs), LXR $\alpha$ and LXR $\beta$, are ligand-activated transcription factors that belong to the nuclear hormone receptor superfamily. The majority of LXR-responsive genes are involved in cholesterol metabolism and transport, lipoprotein remodeling, and lipogenesis (Kalaany and Mangelsdorf, 2005). LXR target genes such as ATP-binding cassette transporter A1 (ABCA1), ATP-binding cassette transporter G1 (ABCG1), and human apolipoprotein E gene (APOE) regulate cholesterol efflux and the formation of high-density lipoprotein particles (HDL) (Shibata and Glass, 2009). Lack of either LXR $\alpha$ or LXR $\beta$ in Alzheimer's disease (AD) model mice (APP transgenic mice) increases amyloid deposition (Zelcer et al., 2007). We and others also reported

\footnotetext{
Received March 1, 2010; revised March 25, 2010; accepted March 31, 2010.

This work was supported in part by National Institutes of Health/National Institute on Aging (NIA) Grants AG027973 (R.K.) and AG031956 (I.L.) and University of Pittsburgh Alzheimer Disease Research Center Pilot Grant P50 AG005133 (N.F.); Alzheimer Association Investigator-Initiated Research Grant 0627077 (R.K.); and Alzheimer's Art Quilt Initiative Grant (N.F.). N.F. is supported by an NIA F32 fellowship. The content is solely responsibility of the authors and does not necessarily represent the official views of the National Institute on Aging, National Institutes of Health, or the private foundations. We are grateful to Charles Glabe and Jessica Wu (University of California, Irvine, Irvine, (A) for providing A11 antibody and J. Cirrito and D. Holtzman (Washington University, St Louis, M0) for the helpful suggestions and advice on microdialysis experiments.

Correspondence should be addressed to lliya Lefterov or Radosveta Koldamova, Department of Environmental and Occupational Health, University of Pittsburgh, 100 Technology Drive, Bridgeside Point, Pittsburgh, PA 15219. E-mail: iliya@ @itt.edu or radak@pitt.edu.

DOI:10.1523/JNEUROSCI.1051-10.2010

Copyright $\odot 2010$ the authors $\quad 0270-6474 / 10 / 306862-11 \$ 15.00 / 0$
}

that global deletion of Abcal in APP transgenic mice increased the level of $\mathrm{A} \beta$ plaques (Hirsch-Reinshagen et al., 2005; Koldamova et al., 2005a; Wahrle et al., 2005).

A recent report from our group demonstrated that APP23 mice with one functional copy of Abcal have significant memory deficits that correlate with the levels of soluble $\mathrm{A} \beta$ oligomers (Lefterov et al., 2009). It has also been demonstrated that treatment with LXR agonists decreased $\mathrm{A} \beta$ levels and amyloid plaques in APP transgenic mice (Koldamova et al., 2005b; Riddell et al., 2007; Jiang et al., 2008). In addition, we have shown that chronic LXR ligand treatment upregulates genes related to lipid metabolism/transport, metabolism of xenobiotics, and detoxification and downregulates genes involved in immune response and inflammation, cell death, and apoptosis (Lefterov et al., 2007).

There is increasing evidence that some dietary patterns, specifically high-fat/high-cholesterol (HF) diets, increase the risk of developing sporadic AD (Kivipelto et al., 2002; Scarmeas et al., 2006). The earlier discovery that inheritance of the APOE 4 allele is a major genetic risk factor for vascular dementia and sporadic AD (Corder et al., 1993; Poirier et al., 1993), as well as reports that high dietary cholesterol increases $A \beta$ accumulation in experimental animals (Refolo et al., 2000; Refolo et al., 2001; George et al., 2004), have reinforced the efforts to reveal the relationship between cholesterol and AD. Epidemiological studies have associated statins, a class of cholesterol-lowering drugs, with a lower prevalence of $\mathrm{AD}$ and slower decline in cognition associated with 
aging (Jick et al., 2000; Zandi et al., 2005). A systematic study addressing the effect of HF diet on cognition in experimental $\mathrm{AD}$ animal models, however, is missing. Specifically, it remains unclear whether a modulatory effect on brain cholesterol metabolism can change the development and course of $\mathrm{AD}$ pathogenesis. Here, we report that Western-type HF diet provided for a relatively long period of time (4 months) exacerbates AD phenotype in APP23 mice, while treatment with an LXR agonist ameliorated this effect. Our data show that the LXR ligand T0901317 (T0) significantly decreases amyloid pathology caused by high-cholesterol diet, which correlated with improved cognitive performance.

\section{Materials and Methods}

Chemicals and reagents

T0901317 (T0) was from Cayman Chemical. Probes and primers for RT-QPCR were from Applied Biosystems. All other reagents and materials for cell culture and general use (if not specified) were from Invitrogen and Fisher Scientific, respectively.

\section{Animals and diets}

All animal experiments were approved by the University of Pittsburgh Institutional Animal Care and Use Committee. APP23 transgenic mice (C57BL/6 background) express human APP751 familial Swedish AD mutant (APPK670N, M671L), and the expression of the transgene is driven by the murine Thy-1 promoter, restricted to neurons (SturchlerPierrat et al., 1997). Wild-type C57BL/6 mice were crossed to APP23 mice to generate APP23 hemizygous mice used in this study. APP23 mice $8-10$ months old (mean age 9.3 months) were randomly assigned to one of three diets/treatments: normal diet (ND)-vehicle treatment (NDVeh, 6 females and 8 males), HF diet-vehicle treatment (HF-Veh, 8 females and 8 males), or HF diet-T0 treatment (HF-T0, 7 females and 8 males). Based on the average APP23 mouse weight, at 8-14 months of age ( $25 \mathrm{~g})$ and on average mouse food consumption ( $5 \mathrm{~g} / \mathrm{d})$, experimental food was prepared in a $0.028 \%$ drug in food (w/w) preparation-a concentration corresponding to a dose of $25 \mathrm{mg} / \mathrm{kg}$ of body weight per day. The diet was prepared by dissolving T0901317 in dimethyl sulfoxide (DMSO) as vehicle and mixing it together with milled control diet (7001 Teklad 4\% Mouse Diet, Harlan Teklad) or milled high-cholesterol diet (D12079B RD Western Diet, Research Diets) to a concentration of $<1 \%$ DMSO in food. Consequently, the milled diets were reconstituted with double-distilled water, divided into daily portions, and dried to achieve a $0.028 \%(\mathrm{w} / \mathrm{w})$ drug concentration in food. Chow for the vehicle-treated group was prepared likewise, containing only the vehicle DMSO. Mice were subjected to behavioral testing after 4 months on the corresponding diet, with behavior assessed at 12-14 (mean age 13.5) months of age. As nontransgenic controls, we used gender and age-matched wild-type (WT) mice fed the same ND and HF diets supplemented with T0 or vehicle.

For microdialysis experiments, 4- to 5-month-old APP23 mice were treated with the same HF diet supplemented with the same dose of T0 (as the main group) for 3 weeks. The control mice received HF diet with vehicle for the same period of time.

\section{Morris water maze}

Behavior was performed with a modified version of the Morris water maze (MWM) used to assess spatial navigation learning and memory retention as before (Lefterov et al., 2009) with minor modifications. Initially, animals received a habituation trial during which the animals were handled for several minutes by the experimenter and allowed to explore the pool of water (diameter $122 \mathrm{~cm}$, height $51 \mathrm{~cm}$, temperature $21 \pm 1^{\circ} \mathrm{C}$ ) without the platform present.

Visual cue phase. Following habituation, visible platform training was performed to measure motivation of the mice to find a platform, visual acuity of the mice, and the ability of mice to use local cues. Briefly, distal cues were removed from around the maze, and the platform was labeled with a flag and placed $1 \mathrm{~cm}$ above the surface of the water in the center of a quadrant. Mice were placed in the maze and allowed to explore the maze for $60 \mathrm{~s}$, and if they reached the visible platform, they remained there for $20 \mathrm{~s}$ before being returned to their cages. If they did not find the platform within $60 \mathrm{~s}$, they were led there by the experimenter and remained there for $20 \mathrm{~s}$. Once all animals in a group completed a trial, the position of the platform and the start position were changed. Each platform and start position was equal distance apart. Animals were trained in groups of five, and training was completed once each animal received six trials. This same training was performed for 2 consecutive days.

Acquisition phase. We measured the ability of mice to form a representation of the spatial relationship between a safe, but invisible (submerged $1 \mathrm{~cm}$ below the water level), platform ( $10 \mathrm{~cm}$ in diameter) and visual cues surrounding the maze. The platform was located in the center of one of the four quadrants, and several extramaze cues were distributed across the walls surrounding the pool. During the acquisition phase of training, each mouse received four daily hidden platform training trials with 10-12 min intertrial intervals for 5 consecutive days. Animals were allowed $60 \mathrm{~s}$ to locate the platform and $20 \mathrm{~s}$ to rest on it. Mice that failed to find the platform were led there by the experimenter and allowed to rest there for $20 \mathrm{~s}$.

Probe trial phase. Twenty-four hours following the last acquisition trial; a single $60 \mathrm{~s}$ probe trial was administered to assess spatial memory retention. For the probe trial, animals were returned to the maze as during training, but with no platform present, and parameters were recorded to assess the ability of the mouse to remember the previous location of the platform.

Performance was recorded with an automated tracking system (AnyMaze; Stoelting) during all phases of training. During the visual cue phase of training, speed and latency to the platform were used to compare the performance between different treatment groups. During the acquisition phase, acquisition time (latency to reach the platform) and path length (distance swam to the platform) were subsequently used to analyze and compare the performance between different treatment groups. The time spent in each of the four quadrants, the number of crossings of the former platform location, time to the former platform location, time to the platform quadrant, and the number of entries into the target quadrant were recorded and analyzed during the probe trials. Mice with swimming speed significantly lower than the average were excluded from the analysis (according to this criterion, two mice on high-fat diet vehicle were excluded).

\section{In vivo microdialysis}

In vivo microdialysis to assess brain interstitial fluid (ISF) $\mathrm{A} \beta_{40}$ and $\mathrm{A} \beta_{42}$ in the hippocampus of awake, freely moving APP23 mice was performed as previously described with minor changes (Cirrito et al., 2003). For microdialysis guide cannula implantation, APP23 mice were anesthetized with Avertin (i.p., $250 \mathrm{mg} / \mathrm{kg}$ ), their heads shaven and placed into a stereotaxic frame (Stoelting). An incision was made exposing the dorsal aspect of the skull, and the head was leveled by ensuring that bregma and lambda were at equal heights, as well as two points equidistant from midline (with $0.1 \mathrm{~mm}$ tolerance). A bore hole $(0.75 \mathrm{~mm}$ ) was made above the left hippocampus (coordinate: $-3.1 \mathrm{~mm}$ from bregma, 2.4 lateral), as well as the right aspect of the skull for placement of an anchoring screw. MD-2250 guide cannulas (Bioanalytical Systems) were stereotactically lowered into the hippocampus $\left(12^{\circ}\right.$ angle, $-0.6 \mathrm{~mm}$ relative to dura mater) and anchored to the bone screw using binary dental cement. Once the cement was hardened, the incision was sutured and the animal was removed from the stereotaxic frame. Before insertion of the MD-2200 microdialysis probes (Bioanalytical Systems) the probes were connected to a CMA 102 microdialysis pump (CMA Microdialysis) using Teflon (FEP) tubing (inner diameter: $0.12 \mathrm{~mm} ; 1.2 \mu \mathrm{l} / 10 \mathrm{~cm}$; SciPro) and washed with $0.15 \%$ bovine serum albumin (BSA) in artificial CSF (aCSF) perfusion buffer (in mM: $1.3 \mathrm{CaCl}_{2}, 1.2 \mathrm{MgSO}_{4}, 3 \mathrm{KCl}, 0.4 \mathrm{KH}_{2} \mathrm{PO}_{4}, 25$ $\mathrm{NaHCO}_{3}$, and $122 \mathrm{NaCl}, \mathrm{pH} 7.35$ ) that was filtered through a $0.1 \mu \mathrm{m}$ filter (Millipore). After washing of the probes, the microdialysis probes were manually inserted through the guide cannula into the hippocampus and mice were placed into cages designed to allow unrestricted movement of the animal without applying pressure to the probe assembly (Instech). Animals were allowed to awaken and remained awake throughout collection of all microdialysis fractions. To measure $\mathrm{A} \beta_{40}$ 
and $\mathrm{A} \beta_{42}$, microdialysis probes had a constant flow rate of $1.0 \mu \mathrm{l} / \mathrm{min}$ and samples were collected every $75 \mathrm{~min}$ on ice, $12 \mathrm{~h}$ after probe implantation. To determine basal ISF $\mathrm{A} \beta_{40}$ and $\mathrm{A} \beta_{40}$ concentrations, $75 \mathrm{~min}$ samples were taken from hour 12 to hour 16 after probe implantation. At the conclusion of the experiment, probe efficiency was tested by placing the probe in aCSF spiked with synthetic $\mathrm{A} \beta_{40}$ to a concentration of 5 $\mathrm{ng} / \mathrm{ml}$, and $\mathrm{A} \beta_{40}$ concentration in the collected fraction was compared to the known concentration of the standard. All collected fractions were analyzed with ELISA as described later in the Materials and Methods and presented as picograms per milliliter. At the conclusion of the microdialysis experiment, animals were anesthetized with $250 \mathrm{mg} / \mathrm{kg}$ Avertin and perfused with cold $0.1 \mathrm{~m}$ PBS, $\mathrm{pH}$ 7.4. The brain was fixed in $4 \%$ paraformaldehyde at $4^{\circ} \mathrm{C}$ for $48 \mathrm{~h}$ and transferred to $30 \%$ sucrose for storage. To confirm probe placement, brains were sectioned $(30 \mu \mathrm{m})$ on a cryostat and selected sections stained with cresyl violet.

\section{Animal tissue processing}

Mice were anesthetized with Avertin $(250 \mathrm{mg} / \mathrm{kg}$ of body weight, i.p. injection) and perfused transcardially with $25 \mathrm{ml}$ of cold $0.1 \mathrm{M} \mathrm{PBS}, \mathrm{pH}$ 7.4. Brains were rapidly removed and divided into hemispheres, and with one of the hemispheres, the cortex and hippocampus were separated from the olfactory bulbs, subcortical structures, and cerebellum. This hemisphere was snap frozen on dry ice, while the other was drop fixed in $4 \%$ phosphate-buffered paraformaldehyde at $4^{\circ} \mathrm{C}$ for $48 \mathrm{~h}$ before storage in $30 \%$ sucrose.

\section{Histology and immunohistochemistry}

All procedures were as reported previously (Koldamova et al., 2005a; Lefterov et al., 2009) with the following modifications. Histoprepembedded hemibrains were cut in the coronal plane at $30 \mu \mathrm{m}$ sections and stored in a glycol-based cryoprotectant at $-20^{\circ} \mathrm{C}$ until staining. Sections were selected $700 \mu \mathrm{m}$ apart, starting from a randomly chosen section $\sim 150 \mu \mathrm{m}$ caudal to the first appearance of the CA3 and dentate gyrus.

$\mathrm{X}$-34 [1,4-bis(3-carboxy-4-hydroxyphenylethenyl)-benzene] is a highly fluorescent derivative of Congo Red that can be used to detect senile plaques and was provided by W. Klunk (University of Pittsburgh, Pittsburgh, PA). X-34 staining was performed on mounted sections as described previously (Lefterov et al., 2009). Briefly, sections mounted on Superfrost Plus slides were washed in PBS for $10 \mathrm{~min}$ and stained with X-34 $(100 \mu \mathrm{M})$ for $10 \mathrm{~min}$. Following the staining, sections were washed in distilled water with five $1 \mathrm{~s}$ dips, incubated in $0.2 \% \mathrm{NaOH}$ in $80 \%$ unbuffered ethanol for $2 \mathrm{~min}$, washed again in distilled water, and soaked in PBS for $10 \mathrm{~min}$. Microscopic examination was performed using a Nikon Eclipse 80i microscope, and images were captured by a Nikon DS Qi1MC camera. For quantitative analysis, immunostaining in the neocortex and hippocampus was defined as the percentage area covered by X-34 positivity (\% X-34 load). The percentage of immunoreactivity and positivity was determined by examining the entire area of interest for each section using MetaMorph 7.0 (Molecular Devices). For each mouse, $\mathrm{X}$-34-positive plaques were counted in five sections per hemibrain 700 $\mu \mathrm{m}$ apart at a magnification of $20 \times$.

\section{Western blotting, ELISA, and dot blotting for $A \beta$ and APP processing}

The frozen hemibrains (only cortices and hippocampi) were homogenized in tissue homogenization buffer (THB) (250 mM sucrose, $20 \mathrm{~mm}$ Tris base, $1 \mathrm{~mm}$ EDTA, and $1 \mathrm{~mm}$ EGTA, $1 \mathrm{ml}$ per $100 \mathrm{mg}$ of tissue) and protease inhibitors $(10 \mu \mathrm{g} / \mathrm{ml}$ leupeptin, $10 \mu \mathrm{g} / \mathrm{ml}$ aprotinin, and 10 $\mu \mathrm{g} / \mathrm{ml}$ AEBSF). After homogenizing with THB, the brains were additionally extracted with RIPA, TBS, or formic acid.

To detect Abcal, APPfl and C-terminal fragments, results of $\beta$-secretase cleavage $(\mathrm{CTF} \beta)$, protein extracts were prepared by 1:1 dilution of the initial homogenate with $2 \times$ RIPA buffer in the presence of protease inhibitors, and Western blots (WBs) were performed as before (Koldamova et al., 2005a,b). Abcal was detected using monoclonal antibody (ab7360) from Abcam and APPfl and CTF $\beta$ with 6E10 from Covance Research Products. $\beta$-Actin was used as a loading control for all WBs and detected with monoclonal antibody from Santa Cruz Biotechnology.
TBS extraction was used to extract secreted ApoE and apolipoprotein A-I (ApoA-I), secreted soluble sAPP $\alpha$ and sAPP $\beta$ (secreted APP fragments result of $\alpha$ - and $\beta$-secretase cleavages), and soluble A $\beta$ oligomers, and it was performed as before (Koldamova et al., 2005a; Lefterov et al., 2009). sAPP $\alpha$ was detected with $6 \mathrm{E} 10$ and $\operatorname{sAPP} \beta$ with rabbit polyclonal antibody 869 from Novartis (generously provided by M. Staufenbiel, Novartis, Basel, Switzerland). ApoE was detected with M-20 polyclonal antibody from Santa Cruz Biotechnology and ApoA-I with rabbit polyclonal antibody from Rockland. All but $\mathrm{A} \beta$ oligomers were detected by $\mathrm{WB}$ as in the studies by Koldamova et al. (2005a) and Lefterov et al. (2009).

The level of soluble $\mathrm{A} \beta$ oligomers was measured by dot blot assay as before (Kayed et al., 2003; Lefterov et al., 2009). Briefly, soluble amyloid peptide was extracted in TBS with protease inhibitors (see above). After centrifugation at $100,000 \times g$ for $1 \mathrm{~h}$ at $4^{\circ} \mathrm{C}$, the supernatant was analyzed. One microgram of protein was spotted on nitrocellulose membrane and probed with A11 antibody (1:2000), specific for oligomeric forms of $\mathrm{A} \beta$ generously provided by Drs. Charles Glabe and Jessica $\mathrm{Wu}$ (University of California, Irvine, Irvine, CA). The immunoreactive signals were visualized using enhanced chemiluminescence detection kit (GE Healthcare) and quantified densitometrically. The exact same amount of sample were spotted on additional dot blots and probed with $6 \mathrm{E} 10$ and Bradford reagent for normalization.

A $\beta$ ELISA was performed essentially as by Lefterov et al. (2009). Briefly, for extraction of soluble $A \beta$ the initial brain homogenate was mixed 1:1 with $2 \times$ RIPA buffer and samples sonicated for $10 \mathrm{~s}$. After centrifugation at $100,000 \times g$ for $1 \mathrm{~h}$, supernatant was used for determination of soluble $A \beta$ and insoluble $A \beta$ was extracted from the remaining pellet with formic acid as before (Lefterov et al., 2009). ELISA for $A \beta$ was performed using $6 \mathrm{E} 10$ as the capture antibody and anti-A $\beta_{40}(\mathrm{G} 2-10$ $\mathrm{mAb})$ and anti-A $\beta_{42}(\mathrm{G} 2-13 \mathrm{mAb})$ monoclonal antibodies conjugated to horseradish peroxidase (Genetics Company) were used as the detection antibodies (Lefterov et al., 2009). The final values of $A \beta$ were based on $\mathrm{A} \beta_{40}$ and $\mathrm{A} \beta_{42}$ peptide standards (Bachem Biosciences) and normalized amounts of $\mathrm{A} \beta$ were expressed as picomoles per milligram of total protein (for brain) or nanomolar per milligram of total protein (for in vitro experiments).

\section{Cell cultures}

Primary mouse glial cells were derived from newborn WT, Abcal knockout mice, and ApoE knock-out mice. Briefly, cortices and hippocampi were dissociated with $1 \times$ trypsin-EDTA for $10 \mathrm{~min}$ at room temperature and cultivated in DMEM/F12 medium supplemented with 10\% bovine growth serum, L-glutamine, and antibiotics (all reagents from Sigma). Cells were cultured on poly-D-lysine $(100 \mu \mathrm{g} / \mathrm{ml})$-coated T75 Costar flask (Corning). Purified astroglial and microglial cultures were obtained by mild trypsinization as previously described (Lefterov et al., 2007).

\section{Astrocyte-conditioned medium harvesting}

Confluent primary astrocytes were incubated with treatment medium (Neurobasal medium with antibiotics and glutamine as above but without serum) for $48 \mathrm{~h}$. Conditioned medium were collected, immediately filtered through $0.22 \mu \mathrm{M}$ filter, and concentrated $10 \times$ using Amicon Ultra with $10 \mathrm{kDa}$ membrane cutoff (Millipore). Astrocyte-conditioned medium (ACM) was washed extensively (2 times with 10 volumes of PBS). Levels of ApoE protein in the media was assayed by WB as described above. To determine the concentration of ApoE, we used quantitative WB with a standard curve of ApoE from human plasma (Biodesign).

\section{Intracellular $A \beta$ clearance}

Intracellular $A \beta$ clearance was performed as described before (Jiang et al., 2008). Briefly, primary mouse microglia was isolated from ApoE knockout mice. Cells were treated with $200 \mathrm{~nm}$ soluble $A \beta_{42}$ in serum-free medium containing native ApoE particles isolated from ACM as described above and applied at the same time as soluble $A \beta_{42}$. After $24 \mathrm{~h}$, incubation $\mathrm{A} \beta_{42}$ levels in the cell lysates were determined by ELISA. Briefly, cells were washed with PBS to ensure removal of A $\beta$ that was attached to the cell surface. The cells were then lysed in ice-cold EC buffer (20 mu sodium phosphate, 2 mm EDTA, $400 \mathrm{~mm} \mathrm{NaCl}$, 0.2\% BSA, 0.05\% 

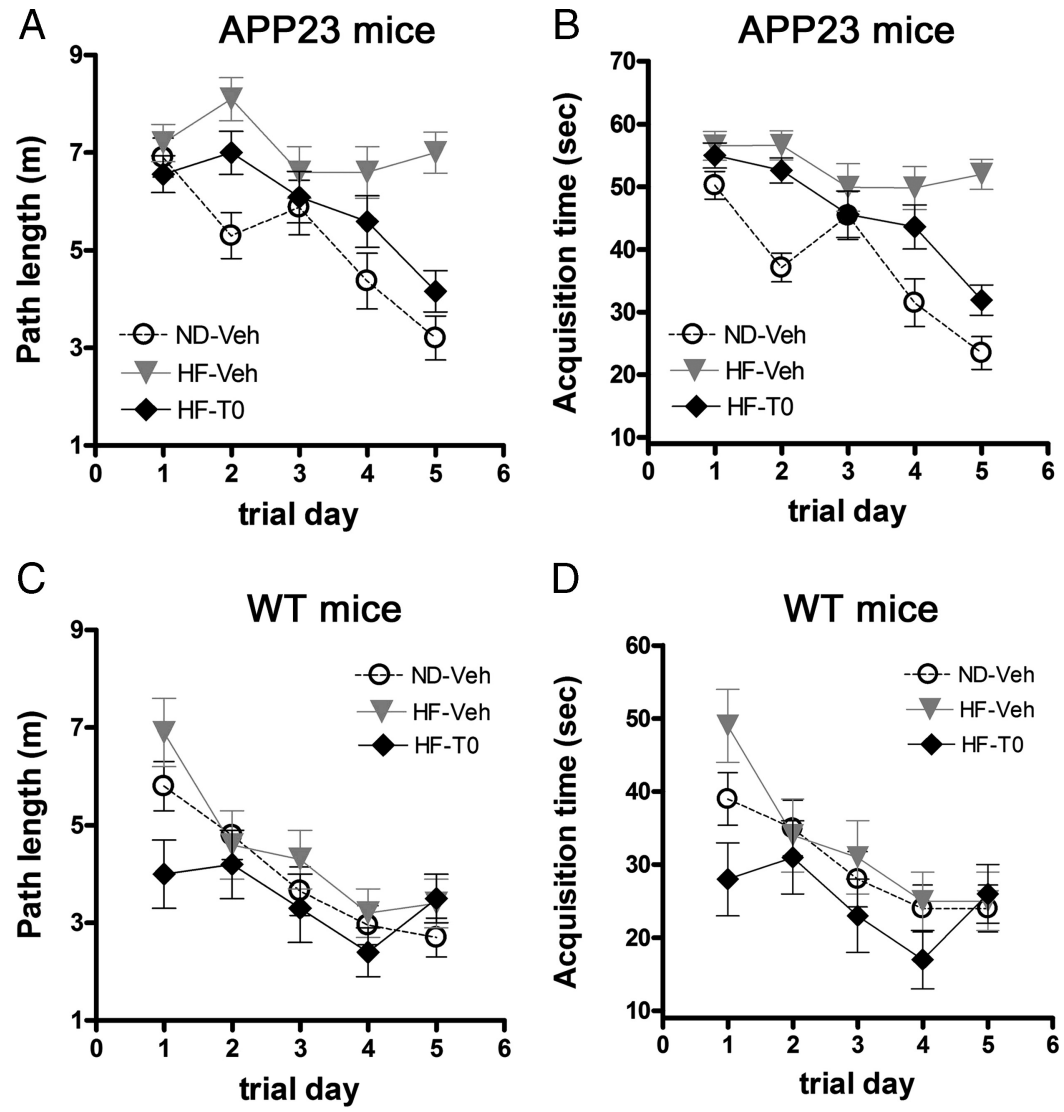

Figure 1. High-fat diet aggravates spatial learning impairment in APP23 mice and T0901317 ameliorates the deficit: MWM acquisition test. $A$, Path length scores represent the average distance swum to find the platform per trial block. (1) There was a significant treatment effect on path length $\left(F_{(2,41)}=10.52, p<0.0001\right)$; (2) a treatment $\times$ trial block interaction significantly affects path length as well $\left(F_{(8,164)}=2.59, p<0.01\right) . p<0.05$, ND-Veh compared to HF-Veh by Tukey's post hoc test. $B$, Escape latency scores represent the average acquisition time to find the platform per trial block. (1) There was a significant treatment effect on escape latency $\left(F_{(2,41)}=18.34, p<0.0001\right)$; (2) similar to the effect on the path length, treatment $\times$ trial block interaction significantly affects the escape latency $\left(F_{(8,164)}=4.02, p<0.0001\right)$. ND-Veh versus HF-Veh, $p<0.05$ by Tukey's post hoc test. $n=14$ APP23 mice per group. $\boldsymbol{C}, \boldsymbol{D}$, Path length $(\boldsymbol{C})$ and acquisition time $(\boldsymbol{D})$ in WT controls subjected to the same diets \pm TO do not show significant difference between the groups. $n=4-12$ WT mice per group. Analysis was performed by RM-ANOVA followed by Tukey's post hoc test for multiple comparisons. All points represent means \pm SEM.

Cholesterol assay

Amplex Red Cholesterol Assay Kit (Invitrogen) was used for quantification of brain and plasma cholesterol levels. Brain samples were diluted 1:5, while sera samples were diluted $1: 2000$ in water.

\section{Statistical analysis}

All results are reported as means \pm SEM. Statistical significance of differences between mean scores during acquisition phase of training in the MWM were assessed with two-way repeated-measures ANOVA (general linear model/RM-ANOVA) and Tukey's post hoc analysis for multiple comparisons using treatment (diet \pm T0) and trial block number as sources of variation. One-way ANOVA with a Tukey's post hoc test was used to evaluate the differences in the parameters during the probe trial. Comparisons of percentage immunoreactivity, X-34 staining, and total cholesterol levels between treatments were performed using one-way ANOVA with Newman-Keuls post hoc test. Pairwise comparisons were performed using Student's $t$ test. All statistical analyses were performed in GraphPad Prism version 4.0 or SPSS version 16, released 2008, and differences considered significant where $p<0.05$.

\section{Results}

High-fat diet exacerbates cognitive performance in APP23 mice, and T0 ameliorates this effect

To assess the effect of HF diet on cognitive performance in APP23 mice, we used the MWM paradigm for testing spatial learning and memory retention. APP23 mice at age 8-10 months were fed HF diet for 4 months, treated with T0 (HF-T0) or vehicle (HF-Veh), and compared to age- and gender-matched APP23 mice on a normal diet (ND-Veh). Since our goal was to examine the therapeutic potential of an LXR agonist, we chose 8- to 10-month-old

CHAPS, $0.4 \%$ Block Ace, and $0.05 \% \mathrm{NaN}_{3}, \mathrm{pH} 7.0$ ), sonicated briefly, and finally collected by centrifugation at $13,000 \mathrm{rpm}$ at $4^{\circ} \mathrm{C}$ for $15 \mathrm{~min}$. $\mathrm{A} \beta_{42}$ levels were measured using ELISA and normalized to the total protein concentration in cell lysate. To determine the level of $A \beta_{42}$ remaining in the media, aliquots were subjected to ELISA for $\mathrm{A} \beta_{42}$ or WB using 6E10 antibody.

\section{$A \beta$ degradation in $A C M$}

To determine the degradation of A $\beta$ by ACM, $2.3 \mu \mathrm{g} / \mathrm{ml}(0.5 \mu \mathrm{M}) \mathrm{A} \beta_{42}$ was incubated with ACM isolated from WT or Abcal ${ }^{\text {ko }}$ astrocytes in 100 $\mu \mathrm{l}$ of Neurobasal medium without serum for $24 \mathrm{~h}$ at $37^{\circ} \mathrm{C}$. The controls (referred to as $\mathrm{A} \beta+\mathrm{Veh}$ ) received PBS in the same volume as ACM. At the end of incubation, the level of $A \beta$ was determined by WB using $6 \mathrm{E} 10$ antibody or ELISA as above.

\section{Real-time quantitative PCR}

RT-QPCR was performed as before (Cronican et al., 2010). RNA was purified using RNeasy spin columns (Qiagen) according to the manufacturer's protocol. For TaqMan-based RT-QPCR first-strand cDNA was synthesized using Sprint RT Complete Random Hexamer strips (Clontech) and $300 \mathrm{ng}$ of total RNA. Gene-specific primers and probes were obtained from Applied Biosystems (ABI). Real-time PCR was performed on ABI 7500 PCR System. Amplification plots were analyzed by Comparative $\Delta$ Ct method with $18 \mathrm{~S}$ rRNA as a housekeeping gene.
APP23 mice because at this age they present with visible amyloid plaques in amounts sufficient to perform quantitative evaluations. Neither HF diet nor T0 treatment increased mortality, nor did they affect the motivation of APP23 or WT mice as demonstrated during visual cue phase of the MWM (see supplemental Fig. $1 A$, available at www.jneurosci.org as supplemental material). In addition, the treatment did not affect the locomotor activity of the mice as exemplified by their swimming speed during all phases of training (see supplemental Fig. $1 B, C$, available at www.jneurosci.org as supplemental material). In contrast, and in comparison to the mice on ND, HF diet caused an increase in body weight of vehicle-treated mice by $18 \%$ (supplemental Fig. $1 D$, available at www.jneurosci.org as supplemental material), while T0 treatment resulted in a leaner phenotype (supplemental Fig. $1 D$, available at www.jneurosci.org as supplemental material) $(p<0.05)$. HF diet increased total cholesterol level in the serum but not in the brain (see supplemental Fig. $2 A, B$, available at www.jneurosci.org as supplemental material). In contrast to previous studies (Zanotti et al., 2004), T0 treatment did not increase the level of triglycerides in plasma, but their level was 
increased in liver (see supplemental Fig. 2C,D, available at www. jneurosci.org as supplemental material).

As illustrated in Figure 1, $A$ and $B$, during the acquisition phase APP23 mice on ND improved their performance with daily training exemplified by their path length (Fig. $1 \mathrm{~A}$ ) and acquisition time (Fig. $1 B$ ). Among the mice on HF diet, only T0-treated APP23 mice (HF-T0) showed improved performance with increased training. In contrast, vehicle-treated APP23 on HF diet (HF-Veh) never learned this task as demonstrated by their relatively flat learning curves (Fig. $1 A, B$ ). Between subjects, there was a main effect of treatment $\left(F_{(2,41)}=10.52, p<0.0001\right)$ and a significant difference between vehicle-treated APP23 mice on $\mathrm{ND}$ and HF diet (Fig. $1 A, B)(p<0.05 \mathrm{ND}-\mathrm{Veh}$ vs HF-Veh). Analysis by RM-ANOVA revealed an interaction between treatment and trial block $\left(F_{(8,164)}=2.59, p<0.01\right)$. The factor trial day influenced the performance of APP23 mice on HF diet only if they received T0 treatment. As nontransgenic controls, we used gender- and age-matched WT mice fed the same ND and HF diets supplemented with T0 or vehicle. As demonstrated in Figure 1, $C$ and $D$, neither HF diet nor T0 treatment affected spatial learning of WT mice. Figure 2 shows the performance during the probe trial and demonstrates that HF diet causes significant deficits in memory retention of APP23 mice. As visible from Figure 2, APP23 mice on HF diet spent significantly less time in the target quadrant (Fig. $2 A)$ ( $p<0.01$, HF-Veh vs ND-Veh), and needed more time to enter the target zone and cross the previous location of the platform (Fig. $2 B, C$ ). In contrast, during the probe trial, the performance of APP23 mice fed a HF diet supplemented with T0 did not differ from the performance of the mice on ND (Fig. $2 A-C)$ (compare ND-Veh to HF-T0), and was significantly improved compared to the performance of HF-Veh-treated mice (compare HF-T0 and HF-Veh). As during the acquisition phase, there was no difference in the performance of WT control groups during the probe trial of the MWM. From these results, we conclude that HF diet significantly worsens memory deficits in APP23 mice, while the LXR agonist T0 restores cognitive performance to the basal level.

\section{T0 treatment alleviates the effect of HF diet on amyloid load and insoluble $\mathrm{A} \beta$}

To determine how amyloid pathology corresponds to the memory deficits in mice subjected to behavioral testing, the amount of $\mathrm{A} \beta$ deposited into plaques was examined using immunohistochemistry. Brain sections were stained with X-34 to visualize fibrillar amyloid plaques in brains of APP23 mice fed ND and HF diets (Fig. 3A). As visible from Figure 3, HF diet increased more than fourfold the level of compact amyloid plaques represented by X-34-positive deposits in the hippocampus and cortex (Fig. $3 B, C)(p<0.01$; compare ND-Veh and HF-Veh). In contrast, when the mice on HF diet were treated with T0, their amyloid load did not differ from ND-fed mice and was significantly decreased compared to vehicle-treated APP23 mice on HF diet (Fig. $3 B, C)(p<0.05 ; \mathrm{HF}-\mathrm{Veh}$ vs HF-T0). These results demonstrate that HF diet aggravates amyloid plaque load in already depositing mice, and LXR agonist treatment ameliorates this effect.

Next, we examined how HF diet affects APP processing. As shown on the representative WB in Figure $4 A$ and graphs in supplemental Figure 3 (available at www.jneurosci.org as supplemental material), neither HF diet nor T0 affected APP processing. To determine the level of soluble and insoluble $\mathrm{A} \beta$, proteins were extracted from the cortices and hippocampi first using RIPA buffer, followed by formic acid extraction of plaque-associated amyloid, and $\mathrm{A} \beta_{40}$ and $\mathrm{A} \beta_{42}$ were measured by ELISA. As shown
A
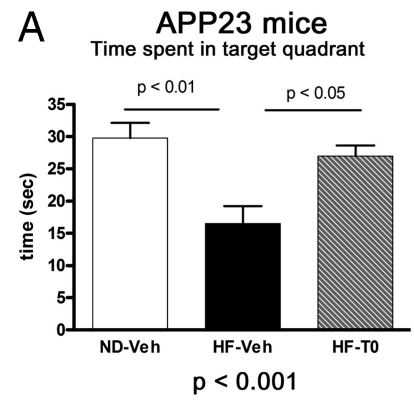

C
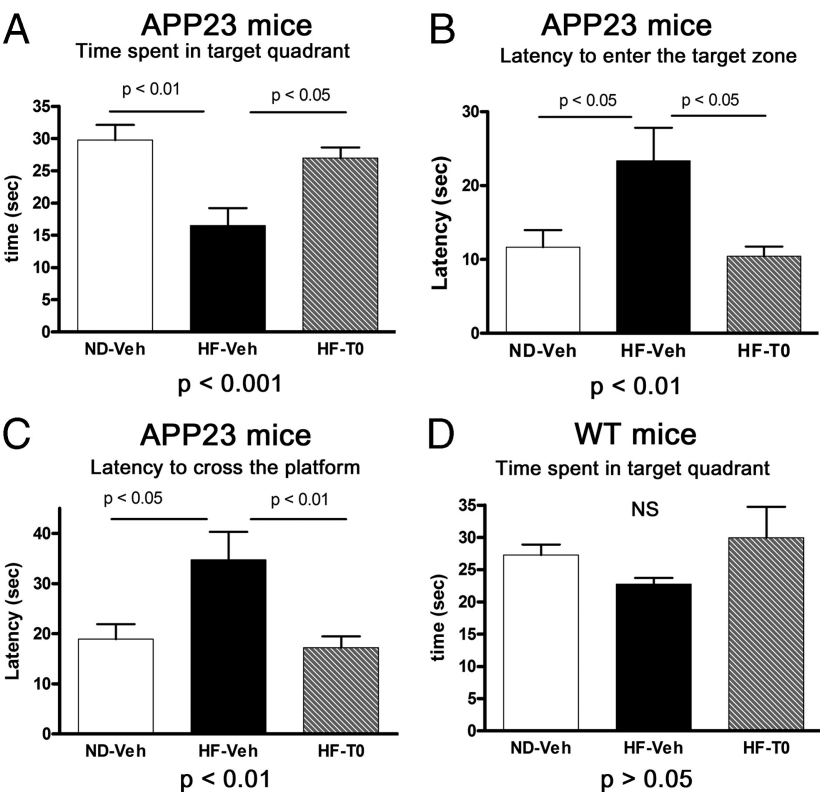

D

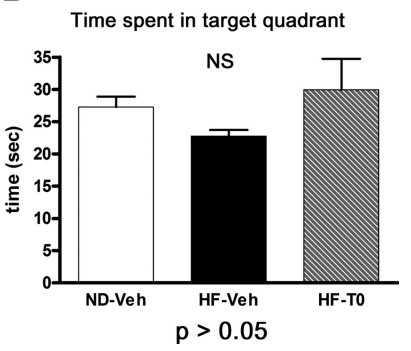

Figure 2. T0901317 restores memory retention deficits in APP23 mice fed HF diet but does not affect WT mice on HF diet: MWM probe trial. $\boldsymbol{A}$, Time spent in the target quadrant is calculated as the amount of time spent in the quadrant where the hidden platform was located during the acquisition phase of training. $\boldsymbol{B}$, Latency to the target quadrant is the time needed for the first entry in the target quadrant. $C$, Latency to cross the target platform is calculated as the amount of time the animal spent before crossing the previous location of the hidden platform. D, Time spent in the target quadrant during the probe trial for WT mice. Analysis was performed by one-way ANOVA followed by Tukey's post hoc test. Bars represent means \pm SEM. $n=14$ APP23 mice. $n=4-12$ WT mice. N.S., No significance.

in Figure 4, $B$ and $C$, HF diet increased soluble $\mathrm{A} \beta_{40}$ and $\mathrm{A} \beta_{42}$ in the cortex ( $p<0.01$, ND-Veh vs HF-Veh), and T0 restored its level to that of ND-fed mice ( $p>0.05$, ND-Veh vs HF-T0). Figure $4, D$ and $E$, demonstrates that HF diet significantly increased the level of insoluble $\mathrm{A} \beta_{40}$ (more than fourfold, $p<0.001$ vs normal diet) and $\mathrm{A} \beta_{42}$ (more than sevenfold, $p<0.01$ ) in the cortex. Treatment with T0 significantly reduced insoluble $\mathrm{A} \beta_{40}$ and $\mathrm{A} \beta_{42}$ (HF-Veh vs HF-T0, $p<0.05$ for both) but did not bring their levels to those in ND-fed mice (ND-Veh vs HF-T0, $p<0.05$ for $\mathrm{A} \beta_{40}$ and $\mathrm{A} \beta_{42}$ ). Similar results for soluble and insoluble $\mathrm{A} \beta$ levels were obtained from ELISA measurements in the hippocampus (data not shown). Therefore, HF diet increases the deposition of insoluble $\mathrm{A} \beta$ and LXR ligand T0 ameliorates this effect, which collectively confirms the results of the X-34 staining.

\section{LXR ligand treatment decreases the level of A11-positive soluble A $\boldsymbol{\beta}$ oligomers in APP23 mice on normal and} high-fat diet

Previously we have shown that in APP23 mice with only one copy of endogenous mouse $\mathrm{Abcal}\left(\mathrm{Abca} 1^{+-}\right.$), the level of soluble $\mathrm{A} \beta$ oligomers correlated with memory deficits (Lefterov et al., 2009). To examine whether the memory deficits correlate with the levels of soluble $A \beta$ oligomers in this study, we performed dot blotting using anti-oligomeric A11 antibody. The A11 antibody is conformation dependent and was shown to detect higher-molecularweight $\mathrm{A} \beta$ oligomers on dot and Western blotting (Kayed et al., 2003; Lefterov et al., 2009). Soluble oligomers were extracted from the cortex and hippocampus of APP23 mice using TBS extraction buffer, and dot blotting was performed with A11 antibody. Staining with $6 \mathrm{E} 10$ antibody, which specifically recognizes $\mathrm{A} \beta$ monomers and fibrils, was used as a control (Kayed et al., 2003; Lefterov et al., 2009). As visible from Figure 5A, there 

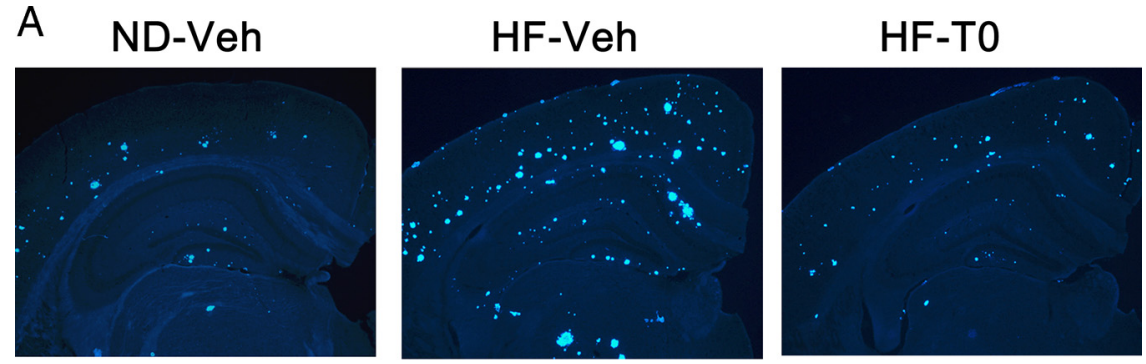

B

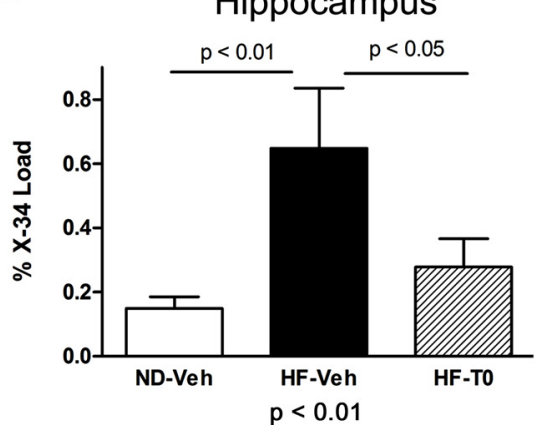

C

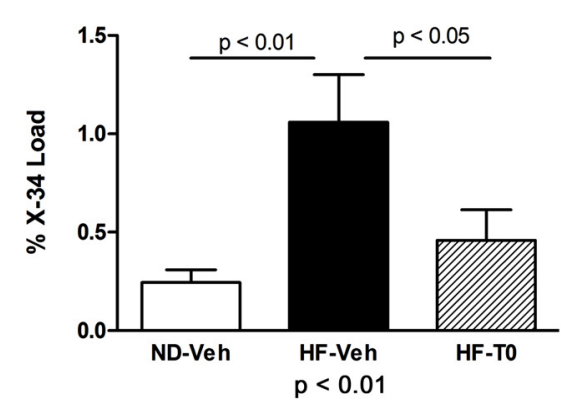

Figure 3. LXR ligand treatment decreases amyloid plaque load in APP23 mice fed high-fat diet. $\boldsymbol{A}$, Brain sections from APP23 mice fed ND-Veh, HF-Veh, and HF-T0 diets were stained with X-34 to visualize fibrillar amyloid plaques. Representative pictures from each group are shown. Magnification is $20 \times$. $B$, Graphical representation of the area of the hippocampus covered by X-34-positive deposits (\% X-34 load). C, Graphical representation of the area of cortex covered by X-34-positive deposits. Note increased X-34 labeled plaques in the HF-Veh group compared to both the ND-Veh and HF-T0. Furthermore, there is no significant difference between ND-Veh and HF-TO. Analysis was performed by one-way ANOVA followed by Newman-Keuls posthoctest. Bars represent means \pm SEM. $n=10-14$ mice per group.

was no difference in $\mathrm{A} \beta$ oligomers in vehicle-treated mice on ND or HF diets. However, T0 treatment caused a significant decrease in soluble A11-positive oligomers in the cortex. ANOVA and post hoc analyses revealed statistically significant difference between APP23 mice on HF diet treated with T0 and vehicle $(p<0.05)$. Furthermore, there was a negative correlation between the level of soluble oligomers in the cortex and probe trial performance of mice on HF diet, suggesting a causative relation between the two (Fig. 5E). Similarly, T0 decreased A11positive oligomers in the hippocampus $(p<0.05)$. In contrast, 6E10 immunoreactivity was decreased by T0 only in the hippocampus, not in the cortex (Fig. $5 D, B$, respectively). Thus, T0 treatment decreases the level of soluble A11-positive $\mathrm{A} \beta$ oligomers in the cortices and hippocampi of APP23 mice on HF diet, which correlates with the effect of this LXR ligand on memory deficits.

LXR agonist treatment increases protein levels of Abcal and ApoE in APP23 mice on high-fat diet

Fist, we examined whether T0 treatment affects Abcal mRNA levels in the cortices and hippocampi of mice fed HF diet and subjected to T0 or vehicle treatment. Figure $6 A$ demonstrates that T0 increased Abcal mRNA in hippocampus ( $p<0.05$, HFVeh vs HF-Veh). Further examination of other LXR-responsive genes revealed that HF diet increased Apoe mRNA in vehicle- and T0-treated mice (Fig. $6 B)(p<0.01$ and 0.001 , respectively). T0 caused small (15\%) and statistically insignificant increase of Apoe mRNA in HF-T0-treated mice compared to HF-Veh (Fig. 6B) $(p>0$ 05). mRNA expression levels of other LXR-responsive genes, namely, Abcg1, ApoD, and SREBP1c, were also increased as a result of LXR ligand treatment (supplemental Fig. $4 A-C$, available at www.jneurosci.org as supplemental material). Simi- lar data were generated with RNA extracted from the cortices (data not shown). We also examined mRNA expression of a few proinflammatory genes. Supplemental Figure 5A (available at www.jneurosci.org as supplemental material) shows that HF diet increased mRNA expression of TNF $\alpha$ in vehicletreated mice ( $p<0.05$ vs ND-Veh), and T0 treatment decreased it, although to a statistically insignificant level. The remaining proinflammatory genes examined in HF diet-fed mice demonstrated a trend towards an increase, but it was not statistically significant (see supplemental Fig. $5 B, C$, available at www.jneurosci.org as supplemental material). It should be noted that IL1 $\beta$ mRNA levels were very low in all samples and undetectable in a few of them.

Next we determined whether upregulation of Abcal and Apoe mRNA translates into an increase of the respective proteins. As shown in Figure 6, $C$ and $D$, HF diet supplemented with T0 increased Abcal $(p<0.001)$ and ApoE $(p<0.01)$ proteins approximately twofold, although HF diet alone had no effect. Thus, although HF diet increased Apoe mRNA levels by $\sim 40 \%$, this increase was not sufficient to affect its protein level. In contrast, the statistically significant increase of ApoE protein in T0treated mice on HF diet is probably a result of its increased stability as was discussed in previous publications (Wahrle et al., 2004; Lefterov et al., 2007). We also examined the protein level of ApoA-I, which is not an LXR target gene, but is involved in Abca1-controlled cholesterol efflux in brain. As visible from Figure $6 E$, neither HF diet nor T0 increased ApoA-I protein.

\section{Lipidation state of ApoE is important for $A \beta$ degradation by} primary microglia

To examine the effect of $\mathrm{T} 0$ on the formation of ApoE-containing lipoprotein particles in vitro, we isolated astrocytes from WT and Abca $1^{\text {ko }}$ mice. We used Abca ${ }^{\text {ko }}$ astrocytes as a negative control because Abcal deficiency abolishes the formation of fully lipidated ApoE native particles in vitro and in vivo (Wahrle et al., 2004). As visible from Figure $7 A, T 0$ increased the total amount of secreted ApoE protein from WT (twofold), and there was a small increase of ApoE secretion by Abca ${ }^{\text {ko }}$ cells (1.2-fold). To determine how T0 affects the formation of ApoE-containing lipoproteins, ACMs from WT and Abca ${ }^{\text {ko }}$ cells were resolved by native gel electrophoresis and compared to ApoE lipid particles in sera. In Figure $7 B$, we show that $\mathrm{T} 0$ increased the amount of lipidated ApoE particles in WT ACM $\left(\mathrm{ACM}^{\mathrm{WT}}+\mathrm{T} 0\right)$ that migrate between 10 and $12 \mathrm{~nm}$ marker corresponding to the size of major serum lipoproteins (Fig. 7B). As expected, in ACM from Abcal ${ }^{\text {ko }}$ cells $\left(\mathrm{ACM}^{\mathrm{ko}}\right)$, these fully lipidated ApoE complexes were completely missing regardless of the treatment (Fig. $7 B$ ). These data demonstrate that LXR ligand T0 increased the amount of lipidated ApoE particles only in the presence of functional Abcal.

To determine whether the amount of lipidated ApoE affects $\mathrm{A} \beta$ clearance by microglia, we used ACM from WT and Abca $1^{\text {ko }}$ cells treated with T0 or vehicle. To avoid the interference of en- 

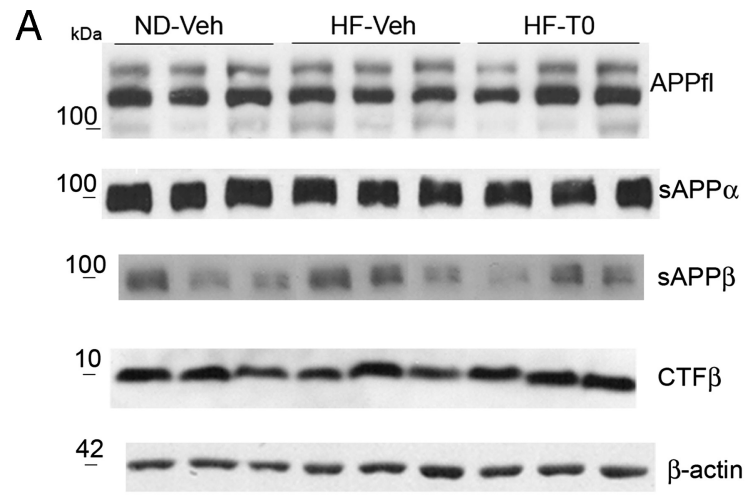

B
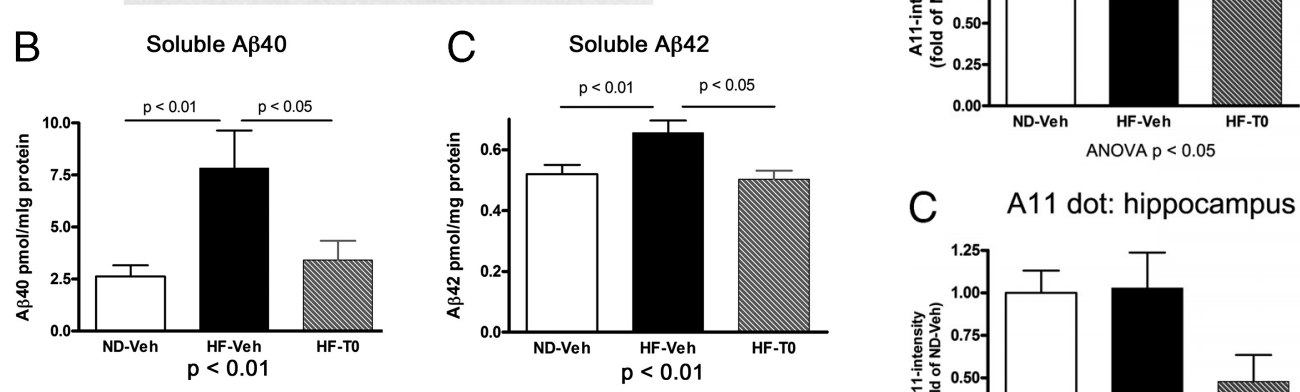

D Insoluble $A \beta 40$
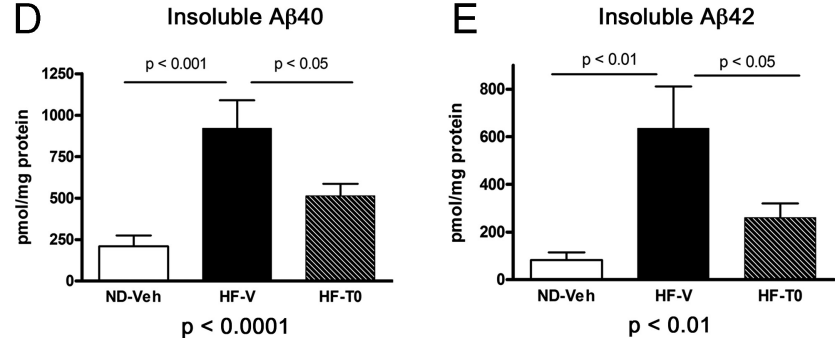

Figure 4. High-fat diet does not affect APP processing but increases soluble and insoluble

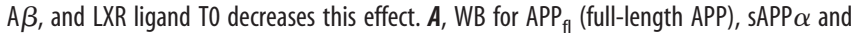
SAPP $\beta$ (soluble fragments resulting from $\alpha$ - and $\beta$-secretase cleavage), and CTF $\beta$ demonstrate that there is no difference in APP processing in mice on normal diet (ND-Veh) and on HF diet treated with vehicle (HF-Veh) or T0 (HF-TO). Representative pictures from three mice per group are shown. The extraction procedures and WB are described in the text. $\boldsymbol{B}-\boldsymbol{E}$, ELISA for soluble and insoluble $A \beta$. Soluble proteins were extracted from cortices of APP23 mice using RIPA buffer followed by extraction of the insoluble proteins from the remaining pellets with formic acid, and ELISA was performed as described in the text. $\boldsymbol{B}, \boldsymbol{C}$, Soluble $A \beta_{40}(\boldsymbol{B})$ and soluble $A \beta_{42}(\boldsymbol{C})$. Note that for $\boldsymbol{B}$ and $\boldsymbol{C}$, there is no difference between ND-Veh and HF-T0 ( $p>0.05$ ). $\boldsymbol{D}$, Insoluble $A \beta_{40}$. $\boldsymbol{E}$, Insoluble $A \beta_{42}$. Note that there is a significant difference between insoluble $A \beta_{40}$ and $A \beta_{42}$ when comparing ND-Veh and HF-T0-treated mice $(p<0.05)$. Analysis was performed by one-way ANOVA and Newman-Keuls post hoc test. $n=10-12$ mice per group. Bars represent means $\pm \mathrm{SEM}$.

dogenously secreted ApoE lipoproteins, for the next experiments we isolated and used microglia from ApoE knock-out mice. As shown in Figure $7 C$, when $A \beta_{42}$ was incubated with ACM from WT cells treated with T0 $\left(\mathrm{ACM}^{\mathrm{WT}}+\mathrm{T} 0\right)$, its degradation by $A p o E^{k o}$ microglia was increased compared to $A \beta$ incubated with ACM from vehicle-treated cells (compare $\mathrm{ACM}^{\mathrm{WT}}+\mathrm{T} 0$ to $\left.\mathrm{ACM}^{\mathrm{WT}}+\mathrm{V}, p<0.01\right)$. In contrast, $\mathrm{ACM}$ from Abcal ${ }^{\text {ko }}$ cells treated with T0 failed to facilitate $\mathrm{A} \beta_{42}$ degradation (Fig. $7 C$, compare $\mathrm{ACM}^{\mathrm{ko}}+\mathrm{T} 0$ to $\left.\mathrm{ACM}^{\mathrm{ko}}+\mathrm{Veh}\right)$. The difference in $\mathrm{A} \beta$ degradation is not a consequence of different uptake of $A \beta$ by ApoE ${ }^{\mathrm{ko}}$ microglia, as $\mathrm{ACM}{ }^{\mathrm{WT}}$ and $\mathrm{ACM}^{\mathrm{ko}}$ had a comparable effect on $\mathrm{A} \beta$ uptake within the first hour of incubation (Fig. $7 C$, the two rightmost columns in the panel). Because previous data suggest that proteases secreted by astrocytes can degrade $A \beta_{42}$ (Jiang et al., 2008), we tested $\mathrm{A} \beta_{42}$ degradation when incubated with ACM without microglia. As visible from supplemental Fig-
A

A11 dot: cortex

ND-Veh HF-Veh HF-TO
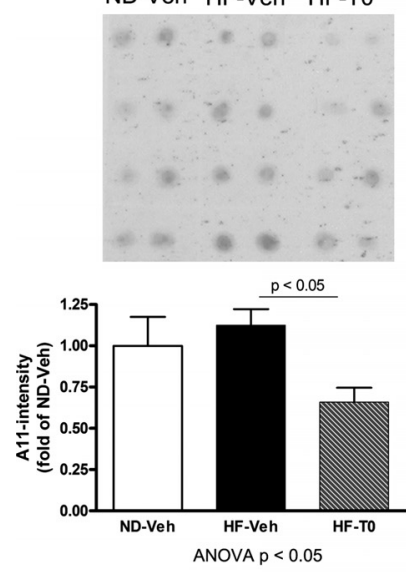

C

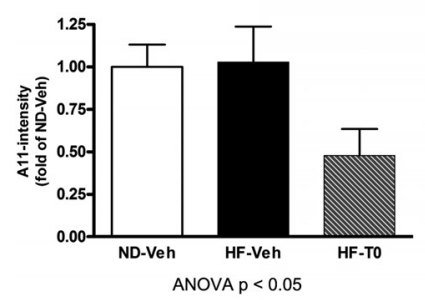

B $6 \mathrm{E} 10$ dot: cortex
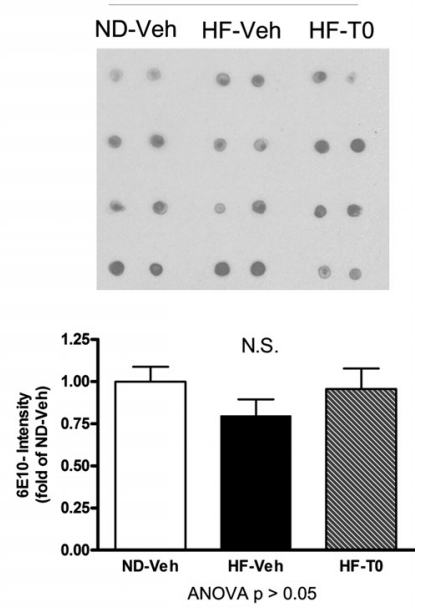

D 6E10 dot: hippocampus

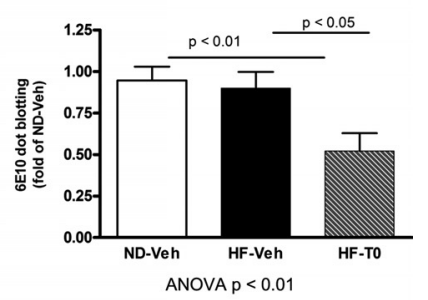

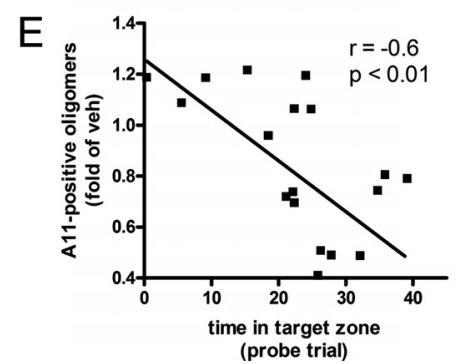

Figure 5. LXR ligand T0 decreases the level of A11-positive soluble A $\beta$ oligomers in APP23 mice on high-fat diet. Soluble $A \beta$ oligomers were extracted from the cortex $(\boldsymbol{A}, \boldsymbol{B})$ and hippocampus $(\boldsymbol{C}, \boldsymbol{D})$ of APP23 mice using TBS buffer, and dot blotting was performed with A11 $(A, C)$ and $6 \mathrm{E} 10$ antibody $(\boldsymbol{B}, \boldsymbol{D})$ as described in the text. $A$ and $B$ show representative dot blots from the cortex of four mice in duplicate from each treatment: ND-Veh, HF-Veh, and HF-TO. The intensity of the dots was quantified, and the data were analyzed by one-way ANOVA followed by Newman-Keuls post hoc test. $E$, Nonparametric correlation analysis demonstrates negative correlation between A11-positive oligomers in cortex and the time spent in the target quadrant during the probe trial. Spearman coefficient $r=-0.6, p<0.01 . n=12-14$ mice per group. Bars represent means \pm SEM. N.S., No significance.

ure 6, $A$ and $B$ (available at www.jneurosci.org as supplemental material), in the absence of microglia there is no difference in $\mathrm{A} \beta$ level when incubated with vehicle alone, $A C M^{\mathrm{WT}}$, or $\mathrm{ACM}^{\mathrm{ko}}$. One possible reason for the discrepancy with the previous study is that a difference in our preparation of ACM compared to Jiang et al. (2008) could lead to inhibition of these proteases. Collectively, our results demonstrate that ACM from WT astrocytes treated with $\mathrm{T} 0$ effectively promote $\mathrm{A} \beta_{42}$ clearance by microglia. Because $\mathrm{T} 0$ failed to produce such an effect when Abca ${ }^{\text {ko }}$ cells were used as a source of ACM, we conclude that the T0 effect on A $\beta$ degradation is a result of increased secretion of fully lipidated ApoE particles.

\section{T0 decreases $A \boldsymbol{\beta}$ levels in brain ISF}

To examine whether T0 increases $\mathrm{A} \beta$ clearance in vivo, we measured its level in brain ISF applying in vivo microdialysis of awake, 

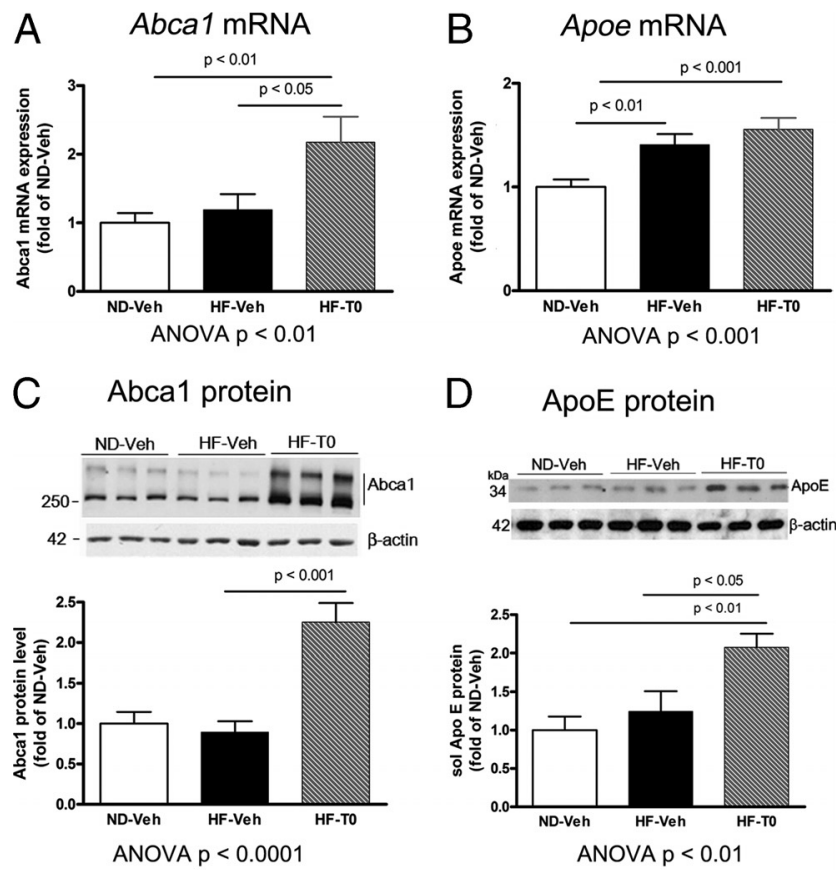

D ApoE protein
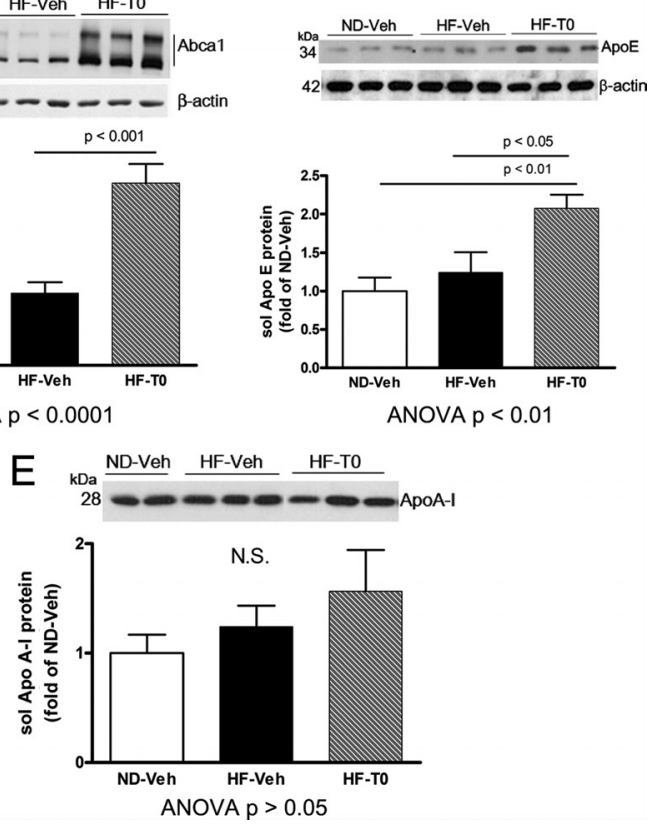

Figure 6. LXR ligand TO increases protein levels of $A b c a 1$ and ApoE in APP 23 mice on high-fat diet. $\boldsymbol{A}$, T0 treatment increases Abca1 mRNA expression in the hippocampus of APP23 mice. $\boldsymbol{B}$, High-fat diet increases the expression of Apoe mRNA similarly in Veh- and T0-treated mice. There was no significant difference between HF-Veh and HF-T0. C, Abca1 was extracted from the hippocampus using RIPA and WB performed as described in the text. D, E, ApoE and ApoA-I proteins were extracted from hippocampus using TBS buffer and WB performed with murinespecific antibodies. Note that the same loading control ( $\beta$-actin) was used to normalize ApoE and ApoA-I. Analysis was performed by one-way ANOVA and Newman-Keuls post hoc test. Bars represent means \pm SEM. $n=12-14$ mice per group. N.S., No significance.

freely moving mice as before (Cirrito et al., 2003). We assessed the concentration of ISF $\mathrm{A} \beta_{40}$ and $\mathrm{A} \beta_{42}$ of young predepositing APP23 mice following HF-T0 or HF-Veh diets for 3 weeks. We specifically chose predepositing mice because previously it was shown that $\mathrm{A} \beta$ aggregation in older mice with amyloid plaques decreases the level of $\mathrm{A} \beta$ that can pass the microdialysis membrane or so-called "exchangeable A $\beta$ " (Cirrito et al., 2003). Microdialysis experiments were performed on the next day after cessation of the diet and T0 treatment. As shown in Figure 8, T0 treatment decreased $\mathrm{A} \beta_{40}$ in ISF by $\sim 40 \%(\mathrm{HF}-\mathrm{T} 0=14.3 \pm 0.5$ $\mathrm{pg} / \mathrm{ml})$ compared to vehicle-treated mice $(\mathrm{HF}-\mathrm{Veh}=23.4 \pm 1.8$ $\mathrm{pg} / \mathrm{ml})$, and the difference was statistically significant $(p<0.01)$. Figure 8 demonstrates that $\mathrm{T} 0$ also caused a small but statistically significant $(p<0.01)$ decrease of $\mathrm{A} \beta_{42}$ concentration in ISF of HF-T0-treated mice (HF-T0 $=18.6 \pm 0.05 \mathrm{pg} / \mathrm{ml}$ ) versus vehicle-treated mice (HF-Veh $=19.8 \pm 0.25 \mathrm{pg} / \mathrm{ml})$ in ISF. These results, together with the lack of effect on APP processing, suggest that $\mathrm{T} 0$ increases $\mathrm{A} \beta$ clearance in the brain.

\section{Discussion}

Sporadic Alzheimer's disease is a late-onset dementia characterized by the presence of senile plaques made of $\mathrm{A} \beta$, neurofibrillary tangles, and cognitive decline. So far, epidemiological and clinical studies have suggested a link between cholesterol metabolism and sporadic AD pathogenesis (Kivipelto et al., 2001, 2005). Despite the therapeutic potential of this link, mechanisms by which cholesterol metabolism influence AD pathogenesis remain uncertain (Puglielli et al., 2003). The LXRs, LXR $\alpha$ and LXR $\beta$, are transcription factors that control the expression of genes involved in cholesterol metabolism (Kalaany and Mangelsdorf, 2005). In the brain, in addition to normal neuronal function, cholesterol metabolism is of utmost importance for secretase activities, APP proteolytic cleavage, and $A \beta$ aggregation and clearance from the brain. Most importantly, APOE, the only proven risk factor for late onset AD (Strittmatter et al., 1993), is an LXR target gene (Laffitte et al., 2001). This is the first study to demonstrate that a treatment can ameliorate both memory deficits and amyloid pathology caused by high-fat/high-cholesterol diet in AD mouse model.

In the present study, we have investigated the effect of LXR agonist treatment on AD phenotype in APP-expressing mice fed HF diet for 4 months. The design of the study considered a therapeutic application of an LXR ligand, and therefore treatment was started at an age when APP23 mice already exhibit deposited amyloid plaques. Our results show that HF diet significantly worsens memory deficits in APP23 mice such that they were completely unable to learn the MWM paradigm task when compared to ND-fed mice. In contrast, our experiments clearly demonstrate a disease-modifying effect of chronic LXR ligand treatment in APP23 mice fed HF diet as exemplified by improved learning curves during the acquisition phase. Furthermore, during the probe trial LXR agonist-treated mice performed remarkably better and did not differ from APP23 mice on ND. The performance of T0- and vehicle-treated mice on HF diet evaluated by multiple-comparison procedures at the end of each of the trial blocks, as well as during the probe trial, confirmed the internal validity of the study.

To gain further insight into the effect of extended T0 treatment on AD phenotype in APP23 mice fed HF diet, we evaluated a number of parameters related to amyloid load and deposition of soluble and fibrillar $\mathrm{A} \beta$ peptides. We did not find an effect of HF diet or T0 treatment on APP processing. Few previous studies reported that high-fat/high-cholesterol diet affects APP processing in APP transgenic mice (Refolo et al., 2000; George et al., 2004; Thirumangalakudi et al., 2008). The reason for this discrepancy is unknown, but it is possible that it is caused by the different composition of the diets (our diet does not contain cholate); the duration of the diet, which continued 4 months in this study as opposed to 6-12 weeks; or the mouse models used in other studies. However, HF diet in vehicle-treated mice led to a significant increase in deposited plaques and fibrillar $\mathrm{A} \beta$, which are well known determinants of memory deficits in APP-expressing mice. On the other hand, treatment with the LXR ligand T0 led to a significant decrease in amyloid load and soluble and insoluble $\mathrm{A} \beta$ levels. In contrast to insoluble $\mathrm{A} \beta$, HF diet did not increase the amount of $\mathrm{A} \beta$ oligomers, but their level was significantly decreased following T0 treatment. Remarkably, the amount of A11positive oligomers correlated significantly with the behavioral phenotype.

Our in vitro data suggest that $\mathrm{A} \beta$ clearance by microglia is affected by ApoE-containing lipoproteins in agreement with a 
recent study by Jiang et al. (2008). Figure 7 demonstrates that the amount of fully lipidated ApoE is important for $\mathrm{A} \beta$ degradation by glia because (1) lipid-poor ApoE produced by Abcal ${ }^{\mathrm{ko}}$ astrocytes is less efficient at promoting $A \beta$ clearance, and (2) T0 facilitates $A \beta$ degradation by increasing the secretion of lipidated ApoE from WT but not from Abcal ${ }^{\text {ko }}$ astrocytes. The results from microdialysis experiments confirm the in vitro data and point to the conclusion that $\mathrm{A} \beta$ clearance is increased following T0 treatment. The level of ISF $A \beta$ in the brain is mainly the result of an equilibrium between its production, degradation by intracellular and extracellular proteases, efflux from the brain, and deposition in plaques. Due to $\mathrm{A} \beta$ deposition in senile plaques, ISF $\mathrm{A} \beta$ levels decrease in older mice. For this reason, we chose to examine the effect of T0 on ISF A $\beta$ levels in mice younger than our original cohort. Collectively the in vitro and microdialysis data presented in this report, together with the lack of effect on APP processing, suggest that T0 facilitates and increases $\mathrm{A} \beta$ clearance.

It is known that as a side effect, treatments with LXR agonists increase serum triglyceride levels, which depends on the mouse strain and duration of the treatment. For example, in WT C57BL/6 mice, short treatment (less than a week) causes an increase in serum triglycerides (Grefhorst et al., 2002), whereas long-term treatment (more than a month) reduced or did not change triglycerides in serum (Peng et al., 2010). In accordance with these studies, we did not find an increase in liver weight (data not shown) and serum triglycerides, but there was an increase in liver triglycerides (supplemental Fig. $2 C, D$, available at www.jneurosci.org as supplemental material).

The behavioral and morphological phenotype of APP23 mice on HF diet raises two important questions. First, what are the consequences of HF diet at the cellular and molecular levels in the brain that cause the observed memory deficits and the increased $\mathrm{A} \beta$ deposition? Based on previous studies, done primarily in vitro (Simons et al., 1998), it is believed that increased intracellular levels or abnormal distribution of cholesterol in the brain can increase $\beta$-and $\gamma$-secretase activities and thus $\mathrm{A} \beta$ production. However, there is no animal model demonstrating that the relatively autonomous brain cholesterol metabolism in the adult mouse can be influenced by systemic hypercholesterolemia resulting from prolonged dietary intake. The results presented here show that HF diet treatment for 4 months does not change the amount of total cholesterol in the brain of vehicle-treated APP23 mice regardless of its increased levels in plasma (supplemental Fig. 2, available at www.jneurosci.org as supplemental material). Although not addressed by this study, HF diet may dysregulate two functionally unrelated physiological systems that independently can exacerbate $\mathrm{AD}$ phenotype: insulin sensitivity in the brain and the intactness of the blood-brain barrier (BBB). Insulin resistance in the brain has been demonstrated in rats fed HF diet, and was implicated as a reason for behavioral deficits (Parrott and Greenwood, 2007). On the other hand, an impairment of the $\mathrm{BBB}$ can allow leakage of circulating lipoprotein- $\mathrm{A} \beta$ complexes into the brain as evidenced by colocalization of plasma lipoproteins (ApoB) and $\mathrm{A} \beta$ in close proximity to cerebral ves-
B

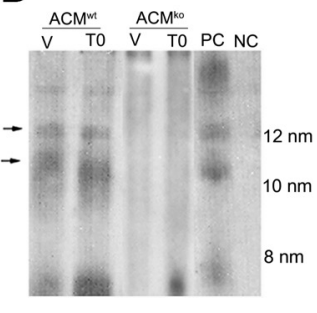

C

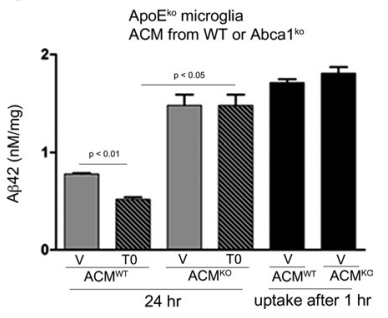

Figure 7. T0 increases the amount of ApoE lipoproteins in WT ACM and facilitates $A \beta_{42}$ degradation by microglia. $A$, Wild-type (wt) and $\mathrm{Abca}^{\mathrm{ko}}(\mathrm{ko})$ astrocytes were treated with $\mathrm{TO}$ or vehicle (V) for $48 \mathrm{~h}$ and the cellular proteins (Cells) and conditioned media 列 the right. Arrowheads on the left point to the size of the major ApoE-containing lipoproteins in ACM ${ }^{W T}$ and WT serum. C, Primary

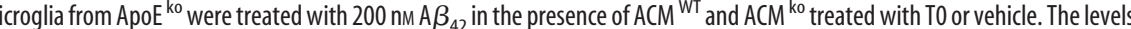
of $A \beta_{42}$ by microglia incubated for $1 \mathrm{~h}$ with $A C M{ }^{W T}$ or $A C M{ }^{k 0}$. Results are representative of three experiments in triplicate. Pairwise comparisons were made by Student's $t$ test.

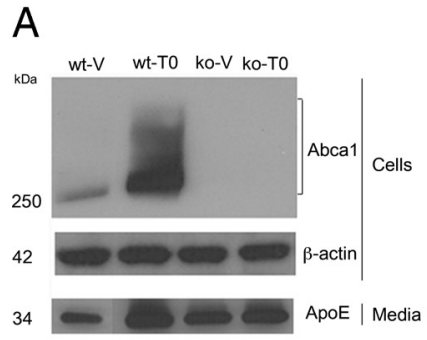

$\mathrm{A} \beta$ level in ISF

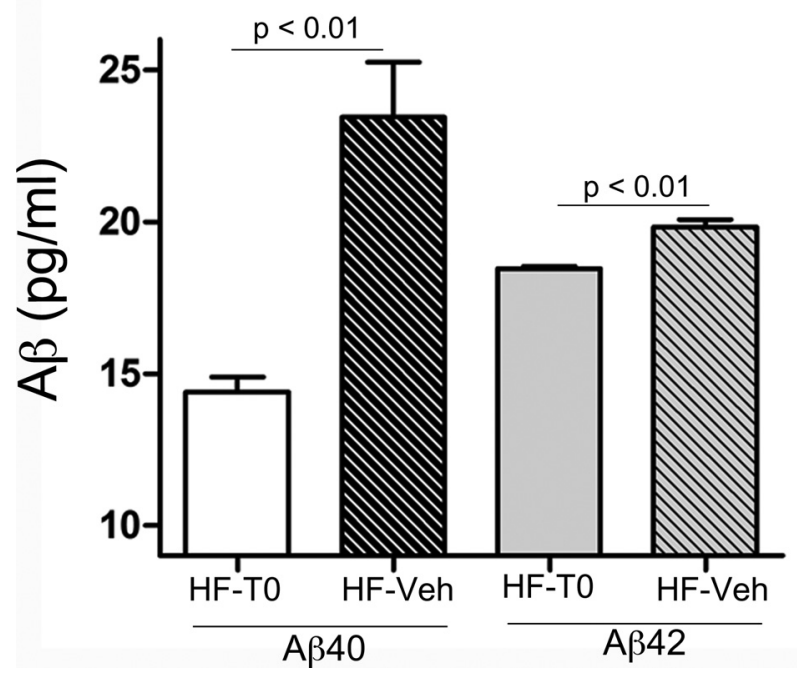

Figure 8. To decreases $A \beta$ levels in brain ISF of mice on high-fat diet. Using in vivo microdialysis, we assessed the concentration of ISF $A \beta_{40}$ and $A \beta_{42}$ within the hippocampus of young predepositing APP23 mice. Four- to five-month-old mice were treated for 3 weeks with high-fat diet supplemented with TO (HF-TO) or vehicle (HF-Veh). Samples were collected at $75 \mathrm{~min}$ interval for $5 \mathrm{~h}$ and assessed for $\mathrm{A} \beta_{40}$ and $A \beta_{42}$ using sandwich ELISA. $n=3-4$ mice per group. Pairwise comparisons were made by Student's $t$ test.

sels, which ultimately exacerbates an AD-like morphological phenotype (Takechi et al., 2010).

The second question is related to the therapeutic effects of synthetic LXR ligands applied to APP23 mice on HF diet. We consider transcriptional upregulation of LXR-responsive genes and functional changes in the brain lipoproteins relevant to deposition and clearance of $\mathrm{A} \beta$ as the most likely mediators of T0 effects on AD phenotype. Previous reports demonstrated that functional impairment of the critical LXR target Abcal have a negative effect on $\mathrm{AD}$ phenotype presumably caused by decreased lipidation of ApoE and ApoA-I and thus an increased aggregation of A $\beta$ (Koldamova and Lefterov, 2007; Lefterov et al., 
2007, 2009; Kim et al., 2009). Activation of LXR by extended application of synthetic ligands has been proven an efficient approach leading to sustainable increases in expression levels of Abca1, Abcg1, and brain lipoproteins_-primarily ApoE, but also ApoD and ApoC1. Presence of functional cholesterol transporters and properly lipidated ApoE and ApoA-I can have a dual effect on the development and progression of pathological phenotypes related to increased $A \beta$ level: first by decreasing $A \beta$ aggregation and second by increasing $A \beta$ clearance. The effect on $\mathrm{A} \beta$ aggregation could directly or indirectly increase $\mathrm{A} \beta$ clearance: directly because properly lipidated ApoE increases $A \beta$ degradation, and indirectly because it would be easier for soluble $A \beta$ to be cleared through the BBB. Our experiments show that LXR agonist treatment effectively increases $A \beta$ degradation only when functional Abcal and LXR are present. The results from the in vitro experiments of this study as well as previously published studies by other groups (Jiang et al., 2008) suggest that properly lipidated brain lipoproteins mediated by functional Abca1 are important for $\mathrm{A} \beta$ degradation.

The overall implications of this study are that high-fat/ cholesterol-containing diets, common in developed countries, can exacerbate $\mathrm{AD}$ pathology, although there may be therapeutic potential for reversing such effects by pharmacological activation of LXR in the brain. This study conclusively shows for the first time that LXR agonist treatment can lessen the detrimental effects of metabolic perturbations on both pathology and cognition due to $\mathrm{A} \beta$ accumulation.

\section{References}

Cirrito JR, May PC, O’Dell MA, Taylor JW, Parsadanian M, Cramer JW, Audia JE, Nissen JS, Bales KR, Paul SM, DeMattos RB, Holtzman DM (2003) In vivo assessment of brain interstitial fluid with microdialysis reveals plaque-associated changes in amyloid-beta metabolism and halflife. J Neurosci 23:8844-8853.

Corder EH, Saunders AM, Strittmatter WJ, Schmechel DE, Gaskell PC, Small GW, Roses AD, Haines JL, Pericak-Vance MA (1993) Gene dose of apolipoprotein E type 4 allele and the risk of Alzheimer's disease in late onset families. Science 261:921-923.

Cronican AA, Fitz NF, Pham T, Fogg A, Kifer B, Koldamova R, Lefterov I (2010) Proton pump inhibitor lansoprazole is a nuclear liver $\mathrm{X}$ receptor agonist. Biochem Pharmacol 79:1310-1316.

George AJ, Holsinger RMD, McLean CA, Laughton KM, Beyreuther K, Evin G, Masters CL, Li QX (2004) APP intracellular domain is increased and soluble $\mathrm{A}[\mathrm{beta}]$ is reduced with diet-induced hypercholesterolemia in a transgenic mouse model of Alzheimer disease. Neurobiol Dis 16:124-132.

Grefhorst A, Elzinga BM, Voshol PJ, Plösch T, Kok T, Bloks VW, van der Sluijs FH, Havekes LM, Romijn JA, Verkade HJ, Kuipers F (2002) Stimulation of lipogenesis by pharmacological activation of the liver $\mathrm{X}$ receptor leads to production of large, triglyceride-rich very low density lipoprotein particles. J Biol Chem 277:34182-34190.

Hirsch-Reinshagen V, Maia LF, Burgess BL, Blain JF, Naus KE, McIsaac SA, Parkinson PF, Chan JY, Tansley GH, Hayden MR, Poirier J, Van Nostrand W, Wellington CL (2005) The absence of ABCA1 decreases soluble ApoE levels but does not diminish amyloid deposition in two murine models of Alzheimer disease. J Biol Chem 280:43243-43256.

Jiang Q, Lee CY, Mandrekar S, Wilkinson B, Cramer P, Zelcer N, Mann K, Lamb B, Willson TM, Collins JL, Richardson JC, Smith JD, Comery TA, Riddell D, Holtzman DM, Tontonoz P, Landreth GE (2008) ApoE promotes the proteolytic degradation of Abeta. Neuron 58:681-693.

Jick H, Zornberg GL, Jick SS, Seshadri S, Drachman DA (2000) Statins and the risk of dementia. Lancet 356:1627-1631.

Kalaany NY, Mangelsdorf DJ (2006) LXRs and FXR: the yin and yang of cholesterol and fat metabolism. Annu Rev Physiol 68:159-191.

Kayed R, Head E, Thompson JL, McIntire TM, Milton SC, Cotman CW, Glabe CG (2003) Common structure of soluble amyloid oligomers implies common mechanism of pathogenesis. Science 300:486-489.
Kim J, Basak JM, Holtzman DM (2009) The role of apolipoprotein E in Alzheimer's disease. Neuron 63:287-303.

Kivipelto M, Helkala EL, Laakso MP, Hänninen T, Hallikainen M, Alhainen K, Soininen H, Tuomilehto J, Nissinen A (2001) Midlife vascular risk factors and Alzheimer's disease in later life: longitudinal, population based study. BMJ 322:1447-1451.

Kivipelto M, Helkala EL, Laakso MP, Hänninen T, Hallikainen M, Alhainen $\mathrm{K}$, Iivonen S, Mannermaa A, Tuomilehto J, Nissinen A, Soininen $\mathrm{H}$ (2002) Apolipoprotein E epsilon4 allele, elevated midlife total cholesterol level, and high midlife systolic blood pressure are independent risk factors for late-life Alzheimer disease. Ann Intern Med 137:149-155.

Kivipelto M, Ngandu T, Fratiglioni L, Viitanen M, Kåreholt I, Winblad B, Helkala EL, Tuomilehto J, Soininen H, Nissinen A (2005) Obesity and vascular risk factors at midlife and the risk of dementia and Alzheimer disease. Arch Neurol 62:1556-1560.

Koldamova R, Lefterov I (2007) Role of LXR and ABCA1 in the pathogenesis of Alzheimer's disease - implications for a new therapeutic approach. Curr Alzheimer Res 4:171-178.

Koldamova R, Staufenbiel M, Lefterov I (2005a) Lack of ABCA1 considerably decreases brain ApoE level and increases amyloid deposition in APP23 mice. J Biol Chem 280:43224-43235.

Koldamova RP, Lefterov IM, Staufenbiel M, Wolfe D, Huang S, Glorioso JC, Walter M, Roth MG, Lazo JS (2005b) The liver X receptor ligand T0901317 decreases amyloid beta production in vitro and in a mouse model of Alzheimer's disease. J Biol Chem 280:4079-4088.

Laffitte BA, Repa JJ, Joseph SB, Wilpitz DC, Kast HR, Mangelsdorf DJ, Tontonoz P (2001) LXRs control lipid-inducible expression of the apolipoprotein E gene in macrophages and adipocytes. Proc Natl Acad Sci U S A 98:507-512.

Lefterov I, Bookout A, Wang Z, Staufenbiel M, Mangelsdorf D, Koldamova R (2007) Expression profiling in APP23 mouse brain: inhibition of Abeta amyloidosis and inflammation in response to LXR agonist treatment. Mol Neurodegener 2:20.

Lefterov I, Fitz N, Cronican A, Lefterov PI, Staufenbiel M, Koldamova RP (2009) Memory deficits in APP23/Abcal+/- mice correlate with the level of Abeta oligomers. ASN Neuro 1:2.

Parrott MD, Greenwood CE (2007) Dietary influences on cognitive function with aging: from high-fat diets to healthful eating. Ann N Y Acad Sci 1114:389-397.

Peng D, Hiipakka RA, Xie JT, Reardon CA, Getz GS, Liao S (2010) Differential effects of activation of liver $\mathrm{X}$ receptor on plasma lipid homeostasis in wild-type and lipoprotein clearance-deficient mice. Atherosclerosis 208:126-133.

Poirier J, Davignon J, Bouthillier D, Kogan S, Bertrand P, Gauthier S (1993) Apolipoprotein E polymorphism and Alzheimer's disease. Lancet 342:697-699.

Puglielli L, Tanzi RE, Kovacs DM (2003) Alzheimer's disease: the cholesterol connection. Nat Neurosci 6:345-351.

Refolo LM, Pappolla MA, Malester B, LaFrancois J, Bryant-Thomas T, Wang R, Tint GS, Sambamurti K, Duff K (2000) Hypercholesterolemia accelerates the Alzheimer's amyloid pathology in a transgenic mouse model. Neurobiol Dis 7:321-331.

Refolo LM, Pappolla MA, LaFrancois J, Malester B, Schmidt SD, ThomasBryant T, Tint GS, Wang R, Mercken M, Petanceska SS, Duff KE (2001) A cholesterol-lowering drug reduces beta-amyloid pathology in a transgenic mouse model of Alzheimer's disease. Neurobiol Dis 8:890-899.

Riddell DR, Zhou H, Comery TA, Kouranova E, Lo CF, Warwick HK, Ring RH, Kirksey Y, Aschmies S, Xu J, Kubek K, Hirst WD, Gonzales C, Chen Y, Murphy E, Leonard S, Vasylyev D, Oganesian A, Martone RL, Pangalos MN, et al. (2007) The LXR agonist TO901317 selectively lowers hippocampal Abeta 42 and improves memory in the Tg2576 mouse model of Alzheimer's disease. Mol Cell Neurosci 34:621-628.

Scarmeas N, Stern Y, Mayeux R, Luchsinger JA (2006) Mediterranean diet, Alzheimer disease, and vascular mediation. Arch Neurol 63:1709-1717.

Shibata N, Glass CK (2009) Regulation of macrophage function in inflammation and atherosclerosis. J Lipid Res 50 Suppl:S277-S281.

Simons M, Keller P, De Strooper B, Beyreuther K, Dotti CG, Simons K (1998) Cholesterol depletion inhibits the generation of beta-amyloid in hippocampal neurons. Proc Natl Acad Sci U S A 95:6460-6464.

Strittmatter WJ, Saunders AM, Schmechel D, Pericak-Vance M, Enghild J, Salvesen GS, Roses AD (1993) Apolipoprotein E: high-avidity binding 
to beta-amyloid and increased frequency of type 4 allele in late-onset familial Alzheimer disease. Proc Natl Acad Sci U S A 90:1977-1981.

Sturchler-Pierrat C, Abramowski D, Duke M, Wiederhold KH, Mistl C, Rothacher S, Ledermann B, Bürki K, Frey P, Paganetti PA, Waridel C, Calhoun ME, Jucker M, Probst A, Staufenbiel M, Sommer B (1997) Two amyloid precursor protein transgenic mouse models with Alzheimer disease-like pathology. Proc Natl Acad Sci U S A 94:13287-13292.

Takechi R, Galloway S, Pallebage-Gamarallage MM, Wellington CL, Johnsen RD, Dhaliwal SS, Mamo JC (2010) Differential effects of dietary fatty acids on the cerebral distribution of plasma-derived apo B lipoproteins with amyloid-beta. Br J Nutr 103:652-662.

Thirumangalakudi L, Prakasam A, Zhang R, Bimonte-Nelson H, Sambamurti K, Kindy MS, Bhat NR (2008) High cholesterol-induced neuroinflammation and amyloid precursor protein processing correlate with loss of working memory in mice. J Neurochem 106:475-485.

Wahrle SE, Jiang H, Parsadanian M, Legleiter J, Han X, Fryer JD, Kowalewski T, Holtzman DM (2004) ABCA1 is required for normal central nervous system ApoE levels and for lipidation of astrocyte-secreted apoE. J Biol Chem 279:40987-40993.

Wahrle SE, Jiang H, Parsadanian M, Hartman RE, Bales KR, Paul SM, Holtzman DM (2005) Deletion of Abcal increases Abeta deposition in the PDAPP transgenic mouse model of Alzheimer disease. J Biol Chem 280:43236-43242.

Zandi PP, Sparks DL, Khachaturian AS, Tschanz J, Norton M, Steinberg M, Welsh-Bohmer KA, Breitner JC (2005) Do statins reduce risk of incident dementia and Alzheimer disease? The Cache County Study. Arch Gen Psychiatry 62:217-224.

Zanotti I, Favari E, Sposito AC, Rothblat GH, Bernini F (2004) Pitavastatin increases ABCA1-mediated lipid efflux from Fu5AH rat hepatoma cells. Biochem Biophys Res Commun 321:670-674.

Zelcer N, Khanlou N, Clare R, Jiang Q, Reed-Geaghan EG, Landreth GE, Vinters HV, Tontonoz P (2007) Attenuation of neuroinflammation and Alzheimer's disease pathology by liver x receptors. Proc Natl Acad Sci U S A 104:10601-10606. 